\title{
Tooth 17
}

National Cancer Institute

\section{Source}

National Cancer Institute. Tooth 17. NCI Thesaurus. Code C94582.

The lower left 3rd molar, as defined by the Universal tooth numbering system. 